\title{
An Analysis of General Secretary Xi Important Exposition on Poverty Alleviation
}

\author{
Huaqiang Yang \\ School of Marxism, Southwest Medical University; Luzhou 646000, China
}

About the author: Yang Huaqiang (1987 -), male, Han nationality, born in Ziyang, Sichuan Province, is an assistant professor of School of Marxism, Southwest Medical University, with a master's degree in law.

Funding: The general project of social governance innovation research center of Sichuan philosophy and Social Sciences key base is "Research on rural moral governance construction path in the perspective of improving rural governance system in the new era" (SHZLQN1804); Luzhou Rural Revitalization and new agricultural education research center "study on the path of rural civilization construction from the perspective of improving rural governance system -- Taking Luzhou City as an example"(SHSK2020010).

\begin{abstract}
The general secretary Xi has made a comprehensive and profound exposition on the work of helping the poor. Its theoretical dimension is: taking Marx's anti-poverty thought as the cornerstone of theory, taking China's traditional culture as the beneficial nourishment and the characteristic socialism's theory of helping the poor as an extension field; the practical significance lies in that the good life should be the focal point of the poverty alleviation practice and the common prosperity as the poverty alleviation. The value orientation of practice, the precise poverty alleviation as the era strategy of poverty alleviation practice, and the support of the will and wisdom as the power source of poverty alleviation practice.
\end{abstract}

Key words: Poverty alleviation work; Theoretical origin; Core meaning

Publication date: April, 2021; Publication online: 30 April, 2021

*Corresponding author: Huaqiang Yang, 289067752@qq.com

General secretary Xi from the historical orientation of socialism with Chinese characteristics, has made a comprehensive and profound discussion on poverty alleviation work, determined the basic strategy of precision poverty alleviation, and established the path of poverty alleviation and development with Chinese characteristics in the new era. It not only provides theoretical guidance for China's current rural revitalization, but also provides a theoretical guidance for China's poverty eradication efforts and provides global poverty governance. China's plan and China's wisdom were introduced.

\section{General Secretary $\mathrm{Xi}$ theory on poverty alleviation}

General Secretary Xi important exposition on poverty alleviation works not only sticks to the basic viewpoints of Marx's classic writers' anti-poverty thoughts, but also absorbs the essence of China's traditional culture.

\subsection{Taking Marxist anti-poverty thought as the theoretical cornerstone}

Marx thought: "in order to" create history ", people must be able to live. But in order to live, we need clothes, food, shelter and other things first. " It reveals the mystery of human historical activities. To meet the needs of people's material life and spiritual life, it is necessary to develop social productivity. The masses of the people are the creators of material wealth, and the decisive achievement of China's poverty alleviation comes from the joint efforts of the broad masses of people; at the same time, the people are also the holders of material wealth, so we should adhere to the development concept of sharing. General Secretary Xi pointed out that in-depth study and exploration of rural poverty and poverty alleviation must follow the basic 
principles of Marx doctrine and take Marx's theory of poverty as the theoretical basis for poverty alleviation.

\subsection{Chinese traditional culture is beneficial}

Every country and nation has its own historical traditions and cultural heritage. General Secretary $\mathrm{Xi}$ attaches great importance to the fine traditional Chinese culture, and believes that culture profoundly affects the way of national development and the formulation of policies. In the practice of poverty alleviation, we must "dig deep into and explain the value of the fine traditional Chinese culture in terms of benevolence, emphasis on the people, integrity, justice, harmony and harmony." The Communist Party of China's practice of poverty alleviation runs through the simple people-oriented thought. Confucius put forward that "protecting the people", "raising the people" and "benefiting the people" as an important part of the rule of virtue, have a profound impact on General Secretary $\mathrm{Xi}$ important exposition on poverty alleviation.

\subsection{Taking the theory of poverty alleviation of} socialism with characteristics as an extended horizon Deng Xiaoping stressed: "poverty is not socialism, let alone communism." "The essence of socialism is to liberate and develop productive forces, eliminate exploitation, eliminate polarization, and ultimately achieve common prosperity." [4] To uphold and develop socialism, China must first eliminate poverty. From reform to poverty alleviation, to large-scale poverty alleviation, and then to targeted poverty alleviation. In order to adapt to the development of the times, the Communist Party of China has put forward a series of major strategic measures, such as rural revitalization, and resolutely won the battle of poverty alleviation in rural areas, ethnic groups, border areas and old revolutionary base areas. Under the guidance of the theory of poverty alleviation with Chinese characteristics and the promotion of practice, remarkable results have been achieved and a new situation of poverty alleviation and development in China has been created.

\section{General Secretary Xi practice on poverty alleviation}

General secretary $\mathrm{Xi}$ important exposition on poverty alleviation is a close combination of theoretical innovation and practical innovation, and is a keen grasp of new contradictions, new situations and new problems.

\subsection{Taking a better life as the focus of poverty alleviation}

General secretary Xi pointed out: "people's yearning for a better life is our goal. "General secretary $\mathrm{Xi}$ general secretary's important point of discussing the important work of poverty alleviation is to closely answer the main points and opinions of "who to support, who to help, how to help and how to retire". It is the eternal theme of the party and the people's cause to continuously pursue a happy and beautiful life on the road of poverty alleviation. In building a well-off society in an all-round way, the most arduous task lies in the countryside, which is the prominent short board of building a well-off society in an all-round way. General secretary Xi said "well-off society is not well-off, the key is to see the townsman ${ }^{[6]}$." Winning the fight against poverty is by no means an overnight success. Party committees and governments at all levels should take the suffering of people's livelihood in mind, and make greater determination to achieve the goal of fighting against poverty, so as to ensure that poverty alleviation has real and effective results.

\subsection{Taking common prosperity as the value goal of poverty alleviation practice}

After 40 years of development and rural developmentoriented poverty alleviation, taking common prosperity as an important value of poverty alleviation has become the cornerstone of the theoretical system of socialism with Chinese characteristics, which is an important theoretical basis for targeted poverty alleviation. "Eliminating poverty, improving people's livelihood and realizing common prosperity are the essential requirements of socialism" General secretary $\mathrm{Xi}$ proposed that the development of the people for the people, the fruits of development should be shared by the people, and the poor people who are particularly concerned about and concerned about the economically underdeveloped areas. The work of poverty alleviation focuses on solving the prominent problems in unbalanced development, and takes the road of poverty alleviation and 
development with Chinese characteristics.

\subsection{Taking targeted poverty alleviation as the time strategy of poverty alleviation practice}

Targeted poverty alleviation is poverty alleviation measures.

Targeted assistance should be targeted at the real poor families and population, so as to achieve the goal of sustainable poverty alleviation. Specifically, it is necessary to achieve six aspects of accurate support objects, project arrangement, fund use, measures to households, village specific personnel, and poverty alleviation effect. China's poverty alleviation work has entered a new stage. The basic concept of "precision" runs through the whole process of poverty alleviation practice. From "six precision" to "five groups", the poverty alleviation practice advocated by General secretary $\mathrm{Xi}$ has gradually formed the system guarantee of policy system, responsibility system, mobilization system, supervision system and examination system.

2.4 Taking supporting the will and wisdom as the power source of poverty alleviation practice

General secretary $\mathrm{Xi}$ put forward: "we must persist in combining poverty alleviation with supporting wisdom and supporting aspiration, and focus on stimulating the inner vitality of poor areas and poor people to get rid of poverty and become rich." In order to get rid of poverty accurately, we should first get rid of poverty subjectively, guide the poor households to change their ideas, and get rid of "wait and depend". General secretary Xi believes that "only by relying on external help, help more, you do not want to" fly ", also can not fundamentally solve the problem. The key to poverty alleviation is to activate the "driving force" and realize the long-term poverty alleviation mechanism. Only from the endogenous driving force can poverty alleviation not return to poverty.

\section{References}

[1] Collected works of Marx and Engels: Volume 1 [M]. Beijing: People's publishing house, 2009:531.

[2] Xi Jinping talks about governing the country [M]. Foreign Language Press, 2014:164.

[3] Selected works of Deng Xiaoping: Volume 3 [M]. Beijing: People's publishing house, 1993:64.

[4] Selected works of Deng Xiaoping: Volume 3 [M]. Beijing: People's publishing house, 1993:373.

[5] Xi Jinping talks about governing the country [M]. Foreign Language Press, 2014:4.

[6] Xi Jinping's poverty alleviation exposition excerpts [M]. Beijing: Central Literature Publishing House, 2018:7.

[7] Xi Jinping talks about governing the country [M]. Foreign Language Press, 2014:189.

[8] Xi Jinping: strengthen the support system, increase policy tilt, focus on precision and strive to conquer the backbone of the $[\mathrm{N}]$. people's daily, 2017-06-25 (01).

[9] Xi Jinping talks about governing the country: second volume [M]. Beijing: Foreign Language Press, 2017:90. 